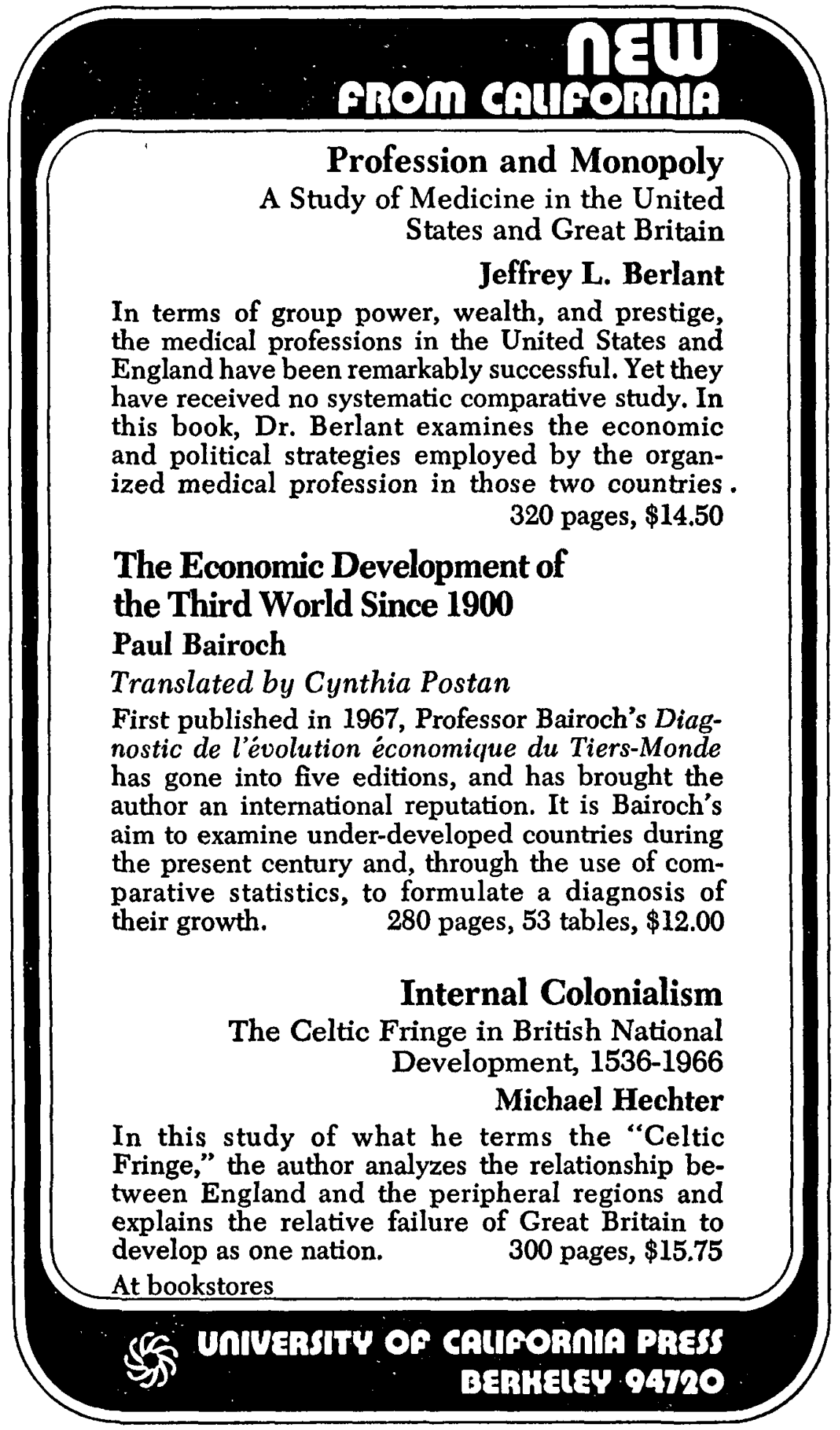




\section{Colonial Development}

\section{An Econometric Study}

Thomas B. Birnberg and

Stephen A. Resnick

This book uses an econometric model to examine the process of economic development for ten Asian, African, and Latin American countries. It shows how they were transformed in a similar pattern from about the start of the twentieth century to the outbreak of World War II.

A Publication of the Economic Growth Center, Yale University $\$ 20.00$

\section{Agricultural Research and Productivity}

Robert E. Evenson and Yoav Kislev The first effort to probe deeply and systematically into the role of agricultural research in producing the type of technology change that can substantially affect food production and the global food problem.

A Publication of the Economic Growth Center, Yale University, in association with the World Bank

Cloth \$1 2.50 Paper \$3.95

\section{Yale University Press \\ New Haven and London}

\section{China's Modern Economy in Historical Perspective}

Dwight H. Perkins, Editor. Why did it take China more than a century after its defeat in the first Opium War to begin systematically acquiring the fruits of modern technology? To what extent did the rapid economic developments after 1949 depend, not on the socialist reorganization of society, but on features unique to China and to Chinese history? These are the major questions examined in this collection of papers which challenges many previously accepted generalizations about China's modern economy. Topics include the effects of foreign imperialism on Chinese economic development, the adequacy of China's financial resources for major economic initiatives, and the influence of the Yenan period on the economic thinking of China's leaders. $\$$ r3.85

\section{Stanford University Press}


ESSAYS IN NINETEENTH CENTURY ECONOMIC HISTORY:

The Old Northwest (1975)

David C. Klingaman and Righard K. Vedder, Editors, Ohio University

These essays by twelve scholars focus on the factors and the institutions that played important roles in the economic growth of the United States between 1800 and 1900. Emphasis is placed on the changes which occurred prior to the Civil War in the five East Central states which make up the "Old Northwest" where the economic transformation was more pronounced. Covering a broad spectrum, the essays analyze the importance of agriculture, land, migration, wealth, banks, canals and the railroad to this growth. "... the collection is of remarkably high quality and even when most innovative or controversial is always interesting to anyone concerned with the state, the region, or the nation in its nineteenth century experience."-MORTON ROTHSTEIN, University of Wisconsin.

\section{CHAPTERS}

1. From Northwest to Mid-West: Social Bases of a Regional History, by William N. Parker

2. The Agricultural Sector and the Pace of Economic Growth: $U$. S. Experience in the Nineteenth Century, by Robert E. Gallman

3. Farm Production and Income in Old and New Areas at Mid-Century, by Richard A. Easterlin

4. Nineteenth Century Public Land Policy: The Case for the Speculator, by Edward H. Rastatter

5. Human Fertility and Agricultural Opportunities in Ohio Counties: From Frontier to Maturity, 1810-60, by Don R. Leet

6. Migration and the Old Northwest, by Richard K. Vedder and Iowell E. Gallaway

7. Individual Wealth in Ohio in 1860, by David C. Klingaman

8. The Growth of Wealth in Ohio, 1800-1969, by Lee Soltow

9. The Role of Banks in the Economic Development of the Old Northwest, by Donald R. Adams

10. Public Canal Investment and the Opening of the Old Northwest, by Roger L. Ransom

11. The Railroads and Midwestern Development, 1870-90: A General Equilibrium History, by Jeffrey G. Williamson 


\section{ADAM SMITH:}

Man of Letters and Economist

\section{by CLYDE E. DANKERT}

author of Contemporary Unionism in the United States

This book paints a fascinating portrait of one of the most significant figures in the intellectual history of Western man, with new insights on present-day relevance. The literary, as well as the economic, aspects of Smith's career are emphasized in Prof. Dankert's collection of essays. This is stimulating reading for both the specialist and non-specialist.

\section{Published by}

\section{EXPOSITION PRESS, INC.}

900 South Oyster Bay Road, Hicksville, New York 11801

(When ordering by mail add 50c to cover postage and handling. NYS residents add applicable sales tax) 


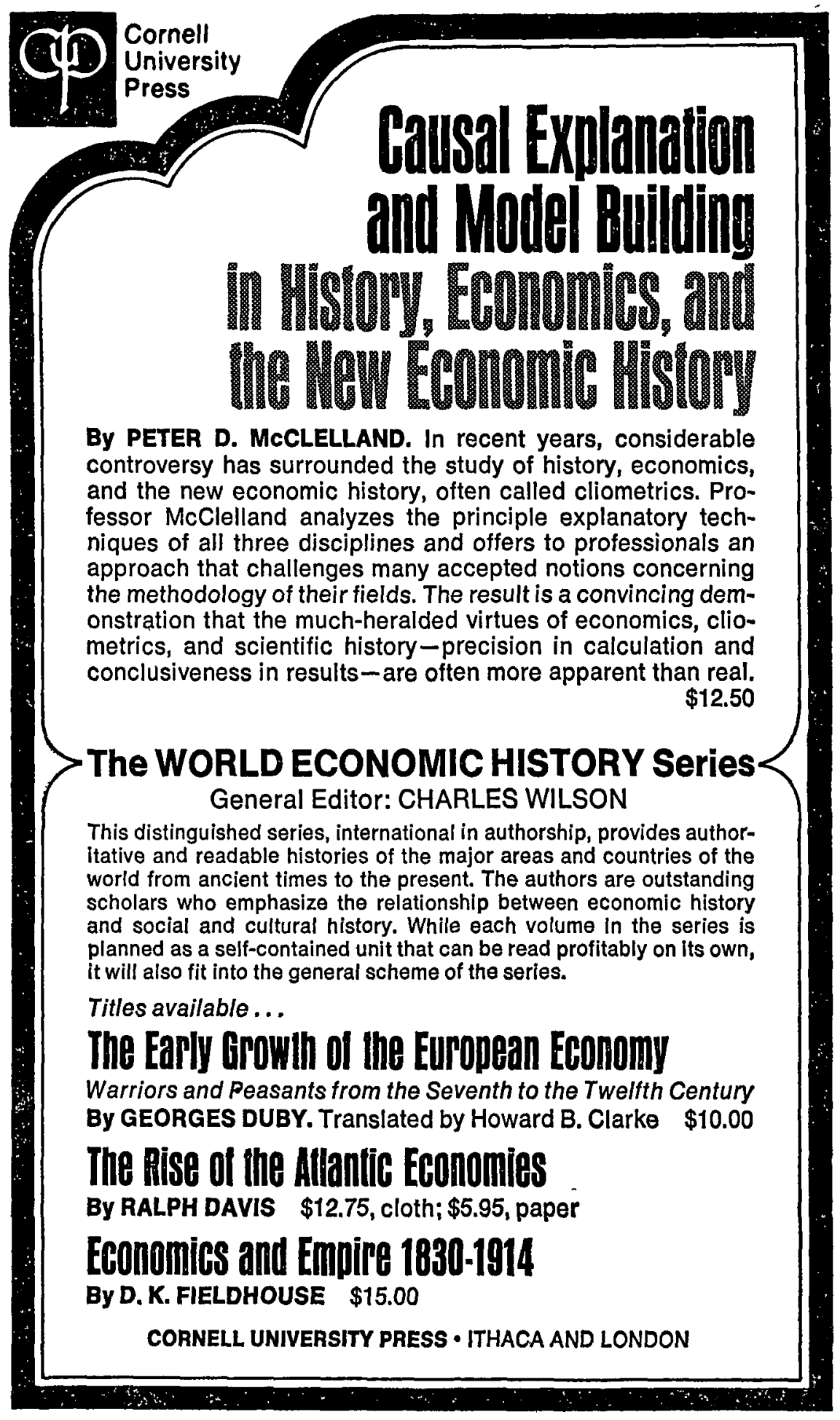




\section{PROGRAM OF THE 1975 MEETINGS OF THE ECONOMIC HISTORY ASSOCIATION}

Pick-Congress Hotel, Chicago, September 18-20

Theme: Aspects of Early Modern Growth

Thursday morning, September 18

Topic: Research Workshops

Convenor: Robert Paul Thomas

University of Washington

Thursday afternoon, September 18

Topic: Rural Developments

Papers:

Richard A. Easterlin, University of Pennsylvania

"Determinants of U.S. Farm Family Fertility in the Mid-Nineteenth Century"

Duane E. Ball, University of Michigan, Dearborn, and Gary M. Walton, Indiana University

"Eighteenth Century Agricultural Productivity Changes in the Middle Atlantic Region"

Thursday evening, September 18

Topic: Dissertation Reports

Convenors: Jan de Vries, University of California, Berkeley Paul Uselding, University of Illinois, Urbana

Friday morning, September 19

Topic: Recruitment of an Industrial Labor Force

Papers:

Tom E. Terrill, University of South Carolina

"Eager Hands: Labor for Southern Textiles, 1850-1860"

Second paper to be announced.

Friday afternoon, September 19

Topic: Control over Wealth

Papers:

David P. Gagan, McMaster University

"Patterns of Inheritance in Nineteenth Century Rural Ontario"

Stanley Lebergott, Wesleyan University

"Long Term Trends in U.S. Wealth Concentration"

Friday evening, September 19

Presidential Address

Rondo Cameron, Emory University

Saturday morning, September 20

Topic: International Flows

Papers:

Alan Green and M. C. Urquhart, Queen's University

"Factor and Commodity Flows in the International Economy, 1870 to 1914: A Multi-Country View"

Robert V. Eagly, Federal Reserve Bank of New York and V. Kerry Smith, S.U.N.Y., Binghamton

"Interest Rate Arbitrage in the Eighteenth Century" 


\section{THE \\ ECONOMIC HISTORY \\ ASSOCIATION}

The Economic History Association was organized in 1940. Its purpose is to encourage research and teaching in the history of economic activity and of economic thought. It seeks to cooperate with societies devoted to the study of agricultural, industrial, and business history. It aims to bring together economists, historians, statisticians, geographers, and others who find that the story of economic change throws light on their field of interest or is enriched by their contribution. Membership is open to all who are interested in the history of economic life in all its phases in the United States and other countries.

The Journal of Economic History is published for The Economic History Association by the Graduate School of Business Administration of New York University. Correspondence concerning contributions to the Journal should be addressed to the editorial office: The Editors, Journal of Economic History, Milton S. Eisenhower Library, The Johns Hopkins University, Baltimore, Maryland 21218. Applications for membership should be addressed to the Secretary-Treasurer, Richmond D. Williams, Eleutherian Mills Historical Library, Wilmington, Delaware 19807. 